\title{
A Company of Russian Machine Guns at the Battle of Liao-Yang
}

\author{
Lieut.-Colonel W. D. Brid D.S.O.
}

To cite this article: Lieut.-Colonel W. D. Brid D.S.O. (1906) A Company of Russian Machine Guns at the Battle of Liao-Yang, Royal United Services Institution. Journal, 50:346, 1498-1503, DOI: 10.1080/03071840609431330

To link to this article: http://dx.doi.org/10.1080/03071840609431330

$$
\text { 曲 Published online: } 11 \text { Sep } 2009 .
$$

Submit your article to this journal $\sqsubset x$

Џ Article views: 4

Q View related articles $\sqsubset$ 


\title{
A COMPANY OF RUSSIAN MACIINE GUNS AT THE BATTLE OF LIAO-YANG. ${ }^{1}$
}

\author{
Translated from the Rezue el'Artillerie, January, 1905, \\ by Lieut.-Colonel IV. D. BInD, D.S.O., Professor, Indian Staff \\ College, Quetta.
}

MOST soldiers are anxiously awaiting the solution of the difficult problem of the best method of employing machine guns in modern warfare, and much has been written and spoken on this subject. Unfortunately, sufficient war experience is not yet available from which to form definite conclusions, for from campaigns such as those which have been recently fought in Cuba and South Africa, where the attendant circumstances differed very widely from those of a European war, none can be drawn. The Russo-Japanese WVar, now raging in the Far East, is, however, on a different footing. Here the conditions approximate to those which nould obtain in Europe, and from careful study of the actions of the combatants, valuable lessons should be learnt. To this end, therefore, a translation has been made of the account of the experiences of a company of Russian machine guns, contributed to the Ruskii Invalial by an officer of the company, and wortlyy of close consideration. (Note by Editor of the Revue d'Artillerie): -

"Vinter has set its iron hand on the face of Manchuria, and for the moment has put an end to active operations, the monotony of camp life being hardly relieved from time to time by some thrilling tale of daring raid on the enemy's outposts. Our own camp at the village of Fou Lin is, lowever, situated far in rear of the front of the army, and lies in full view of the tombs of the Manchu Emperors. Here the short winter days pass busily cnough, but in the long evenings time hangs heavily on our hands, the difficulty being to find occupation for the mind. Papers we read, and read again, full of descriptions of our operations, and one evening, when so engaged, it struck me that no account had, so far as I was aware, yet been published regarding the actions of machine guns in the present campaign. I therefore determined to write a brief description of the experiences of my machine gun company, both during the journey to the front and in three subsequent actions. My company quitted the town of $\mathrm{O}$ __ with all the usual accompaniments of departure for active service-champagne, toasts, and tears-and I was glad when at last we all, 2 officers and 34 men, with guns and equipment complete, but short of horses, were safely in the train and running eastwands. Once on our way we soon settled down, and then, as there was nothing to do but arrange for the food of my command, I had ample leisure to. look about me and speculate on what the

1 This paper is somemhat late, but has been printed by special request. 
future had in store. Of all the subjects that kept crossing my brainthe homes we left behind, the enemy to be encountered in frontthe one uppermost in my thoughts was, where shall we receive our proper complement of officers and men, and when shall we be given time to work together and attain cohesion? Headquarters I vaguely knew were at Liao Yang; but dismissed at once the idea that our establishment would be completed at this place, for such a courso would have been tantamount to senting us direct into the line of battle, for which we could not possibly be fit. The problem, however, remained unsolved, and throughout the long journey, it weighed on my mint, for I had spent three years in studying machine guns, and believing myself proficient in their use, was, and am still convinced that the requisite skill and knowledge cannot be acquired in a shorter time. I knew, therefore, that wherever we received the 3 officers and 67 men necessary to complete our establishment, they would be quite raw, and with little or no knowledgo of our special rôle in action. Against these convictions it may, of course, be argued that there are the text books and regulations, but to this I reply that even their existence is not generally known. For instance, I can state as a fact that, in $\Lambda$ ugust, I asked a cavalry commanding officer, who had been in several actions in Southern Manchuria, whether my guns would be of any service in enabling cavalry to combine its own rapidity of movement with the fire-power of iufantry, and, at the same time; offered lim any highly-trained layers. To this he replied :- Machine guns are only useful as employed by the Japanese; and even they have still a good deal to learn about their handling. We don't want layers, our troopers know how to fire their rifles, and we are equally competent to train our own machine gun detachments.'

"On another occasion a colleague, also commanding a machine gun company, was discussing wilh me the tools and labour required to excavate pits for our guns, when we came to the conclusion that to make trenches for 8 machine guns would occupy $120 \mathrm{men}$, with 60 large shovels, from five to six hours, according to the nature of the ground. Whereas, each company possesses only eight shovels, and each number one has under his ortiers a machine gun, a horse, and a cart, which are not easily accommodated, but he unfortunately also carries a rifle and bayonet. It is clear, therefore, that the characteristics and necessities of machine guns are by no means at present fully understoot. One thing, moreover, is certain, that a definite decision must be given regarding the organisation of machine guns.

"Two courses are open: they can either be grouped as a special arm of the service; or one or more guns may form an integral part of each regiment. MIy own opinion is, that the experience of the present war will prove that machine guns should be regarded as a new and distinct arm.

"This is not, however, the time to speculate as to the future of machine guns, and I shall therefore confine myself to describing the part taken by my company in the battle of Liao Yang, on 30th and 31st August, 1904.

Nore.- $\Lambda$ company should comprise 8 machino guns, with a personnel of 95 offeers and men, with 56 horses, if the guns are mounted on carriagos; if on tripods, with pack transport, of 119 officers and men, with 56 horses. 
"We received our baptism of artillery fire on 11th August, at Da-tchi-chao, where men and horses. were for 15 hours exposed to a cross fire. Our losses were small, amounting to only 2 men and I horse wounded, but it was a trying ordeal, and that we all fully realised the very unpleasant sensation of being obliged to remain passive under fire.

"On 29th August, the company was ordered by the general officer commanding the division to which it was attached, to move to the right of the position, where it occupied the southern border of the village of Goutsiatsy, on the night of 29th-30th August. The ground in our vicinity was generally level, and covered with a tall crop of millet, which had been cleared for a distance of 900 paces (about 700 yards).

"Four hundred paces to our left lay the railway embankment; to the left rear were the heights of the main position; in front of these was situated the village of Maietoun, to the south of which were two small hills distant from us some two versts (1 miles).

"These hills and the village of Maietoun were held by the Regiment.

"A little more than two versts (about $1 \frac{1}{4}$ miles) to the front stood the village of Besymiannoi, and three versts (about 2 miles) away the village of Datchjaotsiatsoi was just visible.

"At 8 a.m. on 17th, the Frontier Guards, supported by two companies of the Regiment, placed on the embankment, came into collision with the enemy's advanced troops, near the southernmost hill, where a brief skirmish occurred. About 10 a.m. the Japanese were apparently reinforced, some horsemen appearing near the railway, who, as soon as they came under fire, plunged into the millet to tho west of the line, where, however, their movements were casily visible. Attention being thus attracted to this direction, we observed, at a point about 1,250 to 1,300 paces (about 1,000 yards) from our position, where the millet grew less thickly, a considerable body of cavalry, escorting some pack animals and footmen. These I eventually made out to be a mountain battery, seemingly endeavouring, under cover of the crops, to gain a position from which they could take in reverse the two hills occupied by two battalions of the - Regiment. .

"Such an opportunity was not to be lost. There was no time for ranging, so fire was at once commenced, the first gun opening at 1,200 paces, the remainder, in succession, each employing an elevation greater by 25 paces, e.g., No. 2 gun 1,225 paces, No. 3 gun 1,250 paces, and so on. The effect was instantaneous, for the battery at once attempted to diverge to its right to gain cover from view where the millet grew more thickly. But it was too late, and long before the remnants of the battery disappeared from view, we could see that it had been completely disorganised. The company fired 6,000 rounds, in all, in $1 \frac{1}{2}$ minutes, but the occasion justified this expenditure of ammunition.

"For two hours nothing occurred, even the report of the guns, which occasionally threw a shell in our direction, being lost in the noise of the battle raging on our left.

"About noon, however, men were observed making their way along the railway line, with the apparent intention of creeping forward to the embankment and taking our soldiers in reverse. To check this movement, rapid traversing fire was opened six times, several elevations being employed on each occasion, a course rendered 
necessary by the fact that the Japanese kept advancing man by man from different points.

“Tho enemy's attempts in this direction having been defeated, the Japanese undertook a regular attack against our position, advancing in lines of skirmishers; but in spite of repeated endeavours, were unable, until nightfall, to make substantial progress beyond the' standing millet.

" With the approach of darkness we could no longer shoot with effect, and the Japanese skirmishers were therefore enabled to close to decisive range, and maintain during the night an uninterrupted fusilade, which kept us awake, but caused few casualtics. At daybreak we fired a belt to clear the border of the millet of any sharpshooters who might be lurking there, and this silenced the enemy for half-an-hour. Subsequently, however, a dropping fire commenced, warning us of the presence of a small body of Japanese, who must have crept unobserved to the edge of the area cleared of crops, and soon to show a liead, hand, or pair of glasses, above our parapet, at once attracted a hail of bullets, which came whistling overhead.

"These skirmishers cventually caused so much amoyance that a non-commissioned officer volunteered to sally out with 15 men taken from the horse-holders and orderlies, and drive them off. Seeing the Russians advance, the Japanese, about 25 in number, under an officer, at once came forward to meet them.

"The Japanese officer on being cliarged by Private Ch-_, threw down his sword, and taking his revolver, wounded him iu the foot, but was at once bayonetted by another private, whilst two of his comrades lielped the wounded man back to cover. In the meantime Sergeant S- killed three Japanese with his bayonet, but being unfortunately unable to withdraw it from the body of his third adversary, was shot dead by a fourth, who was, however, at once killed by Private $\mathbf{A}-$, all five bodies falling in one heap. When this brief bayonet fight was ended not a living Japanese remained to our front, and not another shot was fired until 2 p.m. After collecting our trophies-an officer's sword, rifles, etc.-wo were therefore afforded an opportunity for a short rest, and a frugal meal of biscuits and water. At about 3 p.m. a group of Japanese was observed near a culvert on the railway line, one of whom was signalling with a yellow flag. This signalling continued for quite an hour, in spite of the efforts of our sharpshooters, the range, 1,500 paces (about 1,150 yards), being too great for accurate individual practice. I then gave orders to number 4 Section to clear the culvert, and its commander, choosing a favourable moment, just as two Japanese with flags came from under the little bridge, opened rapid fire, his first gun using an elevation of 1,450 paces, his second one of 1,500 paces, with the result that there was no more signalling that day.

"A bout 5 p.m. bodies. of the enemy's skirmishers were observed moving through the millet in the direction of the village of Baitsailiaogouavo, in order to turn our right flank where the crops had been left standing, and to check theso troops rapid fire was maintained at frequent intervals on a road leading through the fields towards the village of Datchjaotsiatai.

"It was not until about 7 p.m. on 31 st, that the Japanese, having learnt of the repulses suffered by their infantry, finally determined to crush the machine guns in Goutsiatsy with artillery, and 
to this end they brought a battery to the village of Datchiaotsiatai, which opened a heavy fire of both shrapnel and common shell.

"In spite of the fact that guns and detachments were well coverad, several casualties soon occurred, and until approach of darkness, we continued to suffer severely from this fire, to which wo could not reply.

"Finally, at 9 p.m., we were ordered to withdraw, having in the two days' fighting lost 30 per cent. of our personnel, killed and wounded, and expended 26,000 rounds of ammunition.

"At 2 a.m. next morning the Japanese assaulted the village with loud cries of "Banzai," but by that time the machine guns were safely behind Liao Yang."

In recognition of the able manner in which the company had been handled, and of the skill and gallantry with which all attempts of the Japanese to take the two hills and village of Maietoun in reverse were defeated, Captain Sourine, the commander, received the 4th Class of the Order of Saint George. The remaining officers were all given decorations, and teu Saint George's crosses were also distributed amongst the rank and file.

\section{Conclusions ay the Editor of the Revue d'Atillerie.}

The first lesson to be learnt from this account is undoubtedly the confirmation of the belief that machine gans cannot cope with artillery. This endorses the experience of 1870 , and has never been seriously contested. Under effective artillery fire machine gun companies can only make the best use of all available cover, conceal their weapons as far as possible, which should present no difficulties, and wait for a favourable chance to reply.

The practical annililation of the Japanese mountain baftery proves; that at distances under 1,100 yards, even when ranging has not been possible, good results can be obtained against troops in movement by the employment of traversing fire combined with progressive elevations.

Fire, it seems, may even be effective against isolatcal skirmishers at these distances, provided that the range can be approximately ascertained.

It is,-moreover, important to note that the macline gun company was apparently.able to maintain superiority of fire over the Japanese skirmishers at ranges exceeding 750 yards, and invariably succeeded in arresting all attempts to advance over open ground. Lastly, the Russians did not fire at ranges exceeding 2,200 yards, where good results would have been more than problematical.

The expenditure of ammunition was by no means excessive. The 6,000 rounds fired on the mountain battery approximately equal the number of bullets contained in 20 shrapnel, and were delivered in about the same time. On the other hand, this expenditure would have involved the employment of at least 400 rifles, and the effects would probably have been less.

Again, to replenish-a consumption of 2,600 rounds in two days' action, or 1,600 rounds per gun per diem, would make no exceptionally heavy demand on the reserves of ammunition available, especially as the Russiau machine gun companies carry 5,850 rounds per gun. 
Apparently, the best results were obtained by the employment of a combination of progressive elevations and traversing, but under this system the expenditure of ammunition must always be large in proportion to the effects produced. It would secm, therefore, that since rariging with machine guns would rarely be possible, and will always be difficult, every opportunity should be seized of using rangefinders, and, above all, of registering, as accurately as possible, all ground within range.

In other words machine gun companies should always be prepared to open a concentrated fire in any direction. 